\title{
NR1D2 Gene
}

National Cancer Institute

\section{Source}

National Cancer Institute. NR1D2 Gene. NCI Thesaurus. Code C101741.

This gene is involved in transcriptional regulation and metabolic processes. 